\title{
Sodium fluoride influences the expression of keratins in cultured keratinocytes
}

\author{
Euridice Prado • Tilmann Wurtz • Didier Ferbus • \\ El-Hassan Shabana $\cdot$ Nadine Forest • \\ Ariane Berdal
}

Received: 14 December 2009 / Accepted: 8 July 2010 /Published online: 1 August 2010

(C) The Author(s) 2010. This article is published with open access at Springerlink.com

\begin{abstract}
Epithelia in lung, skin, and kidney are often exposed to fluoride, and tissue damage in lung and kidney due to fluoride is well documented. Nevertheless, the biological effects of fluoride on epithelia are poorly investigated. In the present study, we report effects of sodium fluoride $(\mathrm{NaF})$ on the differentiation of a human epithelial cell line, HaCaT. These cells may serve as a keratinocyte model, because they express a
\end{abstract}

E. Prado $(\bowtie) \cdot$ T. Wurtz $\cdot$ D. Ferbus $\cdot$ E.-H. Shabana $\cdot$

N. Forest $\cdot$ A. Berdal

Laboratoire de Physiopathologie oro faciale moléculaire, UMRS 872 Groupe 5, CRC, Université Paris 7,

15, rue de l'Ecole de Médecine,

Paris Cedex 75006, France

e-mail: euridice.prado@gmail.com

E. Prado $\cdot$ T. Wurtz $\cdot$ D. Ferbus $\cdot$ E.-H. Shabana $\cdot$ A. Berdal Centre de Recherche des Cordeliers, Université Pierre et Marie Curie, Paris 6, UMRS 872,

Paris 75006, France

E. Prado $\cdot$ T. Wurtz $\cdot$ E.-H. Shabana $\cdot$ A. Berdal Université René Descartes, Paris 5, UMRS 872, Paris 75006, France

E. Prado $\cdot$ T. Wurtz $\cdot$ D. Ferbus $\cdot$ E.-H. Shabana $\cdot$ A. Berdal INSERM, UMRS 872,

Paris 75006, France

T. Wurtz $\cdot$ E.-H. Shabana $\cdot$ N. Forest $\cdot$ A. Berdal Université Paris Denis Diderot, Paris 7 ,

Paris 75005, France wide spectrum of keratins (Ks), and they associate into stratified tissue-like arrangements along with changes in their keratin pattern. $\mathrm{NaF}$ was added to the culture medium at concentrations of 0.5 and $5 \mathrm{mM}$. Cell proliferation remained intact, but cell functions were altered at high dose, and HSP70 was induced. Reverse transcription-polymerase chain reaction and Western blotting revealed that keratin (K) 15 mRNA and protein expression, associated with stratification of epithelia, were inhibited. Also, expression of keratins typical for terminal differentiation, $\mathrm{K} 1$ and $\mathrm{K} 10$, was decreased and so was the expression of the K1/10 regulating enhancer binding protein $\mathrm{c} / \mathrm{EBP}$ alpha. Stratification of $\mathrm{HaCaT}$ cells was abolished at high fluoride dose, as assessed by electron microscopy. The changes in keratin expression were not reversed by withdrawal of fluoride. Taken together, $\mathrm{NaF}$ at high dose blocked terminal differentiation of $\mathrm{HaCaT}$ cells, visible by keratin expression and failing stratification. This effect may disturb tissue formation due to altered cell interactions.

Keywords c/EBP alpha $\cdot$ Differentiation keratinocytes $\cdot$ Keratins $\cdot$ Sodium fluoride

$\begin{array}{ll}\text { Abbreviations } \\ \text { cDNA } & \text { Complementary deoxyribonucleic acid } \\ \text { FCS } & \text { Fetal calf serum } \\ \text { HRP } & \text { Horseradish phosphate } \\ \text { Igs } & \text { Immunoglobulins } \\ \text { IgG } & \text { Immunoglobulin G }\end{array}$




$\begin{array}{ll}\text { Ks K } & \text { Keratin(s) } \\ \text { K1/10 } & \begin{array}{l}\text { Keratins numbered and classified by (Moll } \\ \text { et al. 1982) }\end{array} \\ \text { NaF } & \text { Sodium fluoride } \\ \text { RT-PCR } & \begin{array}{l}\text { Reverse transcription-polymerase chain } \\ \text { reaction }\end{array} \\ \text { RNA } & \text { Ribonucleic acid } \\ \text { SDS } & \text { Sodium dodecyl sulfate } \\ \text { Ta } & \text { Annealing time } \\ \text { UV } & \text { Ultraviolet }\end{array}$

\section{Introduction}

Application of fluoride is a major reason for the decline of dental caries during the last century. Fluoride increases the resistance of mineralized tissues towards acid demineralization, interferes with the formation of dental plaque microorganisms, and promotes mineralization of incipient lesions. The carioprotective effect of fluorides was found to be dual at pre-eruptive (systemic) and post-eruptive (topical) conditions (Hellwig and Lennon 2004). Fluoride-containing products for topic use range up to $100 \mathrm{mg} / 100 \mathrm{~g}$ of excipient and above. These high fluoride concentrations were innocuous for oral soft tissue in clinical studies (Walsh et al. 2010), because the contact with fluoride lasts only for a few minutes. On the other hand, overexposure to fluoride may have dramatic effects ranging from acute, life-threatening poisoning to chronic dental or skeletal fluorosis encompassing tissue malformations. In the domain of epithelial cell biology, fluoride at high doses was shown to have deleterious effects on pulmonary, gastrointestinal, and renal cell functions (Whitford 1990; Thrane et al. 2001; Partanen 2002). Exposure doses depend on the fluoride concentrations in drinking water and nutrients, on local applications for dental care, and on consumption of medical products and anesthetics.

On the cell level, low fluoride doses promote osteoblast proliferation, stimulating bone formation in vitro and in vivo (Farley et al. 1988; Wergedal et al. 1988; Lau et al. 1991). The proliferative activity of fluoride in osteoblasts and also in ameloblasts is biphasic, being mitogenic at micromolar doses but inhibitory for mitosis at millimolar levels. Cell responses to fluoride depend on the cell type; thus, human keratinocytes survive doses up to $10 \mathrm{mM}$, whereas ameloblasts at doses as low as $10 \mu \mathrm{M}$ show significant increase in apoptosis (Dogan et al. 2002; Yan et al. 2007).

Adversary effects of high fluoride doses on tissue formation were related to cell toxicity, i.e., necrosis, induction of apoptosis, and reduced cell proliferation, all having negative influences on the formation and functioning of tissues. The fluoride-induced regulation of cell proliferation involved the activated protein kinase (MAPK) mitogenic pathway in osteoblasts as well as in lung epithelial cells (Thrane et al. 2001). The influence of fluoride also involved the Rho/ ROCK pathway in murine ameloblasts ( $\mathrm{Li}$ et al. 2005). It is likely that many protein effectors can be influenced by fluoride, since multiple enzyme activities in the cytoplasm of diverse cell types, e.g., lactate dehydrogenase anhydrase, serine/threonine phosphatase, and adenylate cyclase, are affected (Hodge and Smith 1977; ten Cate 1999). Fluoride has been associated with cell stress, characterized by the induction of chaperon proteins and antioxidant components. The state of stress is thought of as an intersection, in which the cell decides to proceed to apoptosis or to revert to the original state (Bevilacqua et al. 2010). Stress granules appear in the cytoplasm, containing stored messenger ribonucleic acid (mRNA) as well as chaperon proteins (Kedersha and Anderson 2007), in order to help the fast recovery of cells after stress relieve.

However, fluoride may also change the transcriptome of cultured odontoblasts without the induction of stress markers and without effects on cell proliferation or survival. An altered transcription pattern of tissue-forming components may thereby compromise cell communication and extracellular matrix formation (Wurtz et al. 2008).

Beside mineralized tissues, fluoride also affects epithelial structures, for example, in kidney and lung. However, effects on epithelium formation in general and keratinocytes in particular remain largely nonelucidated. Nevertheless, these cells are often exposed to high fluoride doses. In the oral cavity, the lining stratified epithelium is subjected to high doses of fluoride in different forms including toothpaste, mouthwash, and chewing gum. Lung epithelia are exposed to fluoride from the air (Thrane et al. 2001), and kidney epithelia secrete fluoride that has been ingested for different reasons (Dominguez et al. 1991; 
Turner et al. 1996; Zager and Iwata 1997; Xu et al. 2005).

Formation of epithelia is accompanied by keratinocyte differentiation, during which the pattern of keratin synthesis is changed. Keratins form intermediate filaments in a dynamic equilibrium between a soluble and a fibrillar status. More than 20 keratins have been identified in human tissues (Moll et al. 1982). In stratified epithelia, K15 is expressed (Leube et al. 1988; Lloyd et al. 1995; Waseem et al. 1999; Werner and Munz 2000), as well as polypeptides $\mathrm{K} 1 / \mathrm{K} 10$ and $\mathrm{K} 4 / \mathrm{K} 13$ as pairs (Kirfel et al. 2003; Hatakeyama et al. 2004). K19 is generally expressed by simple epithelial types, though it may occasionally be expressed in stratified epithelia too. The transcriptional regulation of keratins involves calcium ions, cytokines and growth factors, and hormones. Specific promoter binding proteins are identified, including members of the enhancer binding protein family (c/EBPs; Maytin et al. 1999; Shim et al. 2005).

Cultured HaCaT cells, derived from human skin, proliferate in vitro under synthesis of a keratin pattern that corresponds to the basal cell layer of epithelia, i.e., proliferating cells of low degree of differentiation. Notably, K1, K10, and K13 are expressed just like in normal epidermis (Boukamp et al. 1988). After having attained confluency, $\mathrm{HaCaT}$ cells spontaneously form stratified layers, thereby changing their keratin pattern to that of differentiated keratinocytes, particularly inducing K15 (Lloyd et al. 1995; Werner and Munz 2000). Certain pharmacological agents have the capacity to suppress $\mathrm{HaCaT}$ differentiation and alter keratin expression (Hatakeyama et al. 2004). HaCaT differentiation can be suppressed, and keratin expression can be altered by external effectors (Pi et al. 2008). At present, HaCaT cells represent the only clonal cell line that exhibits this type of differentiation.

Here, we study fluoride effects on $\mathrm{HaCaT}$ cells. Such a model to study fluoride effects on epithelia has so far not been available. Our results indicated that fluoride at high dose retarded differentiation of $\mathrm{HaCaT}$ cells. An altered expression pattern of keratin species was detected, and cells concomitantly failed to assemble stratified layers. We concluded that fluoride at high dose could influence cell differentiation, which may help to explain fluoride-induced tissue disturbances.

\section{Materials and methods}

Cell culture

HaCaT cells were kindly provided by Dr. N.E. Fusenig, Division of Carcinogenesis and Differentiation, German Cancer Research Center, Heidelberg. The cells were cultured in Dulbecco's modified Eagle's medium (DMEM) with glutaMax ${ }^{\mathrm{TM}}$, supplemented with $10 \%$ fetal bovine serum (FBS), $100 \mathrm{IU} /$ $\mathrm{ml}$ penicillin, $100 \mu \mathrm{g} / \mathrm{ml}$ streptomycin, and $2.5 \mu \mathrm{g} / \mathrm{ml}$ amphotericin (GIBCO). Cells were seeded at $10^{-5} \mathrm{cell} / \mathrm{ml}$, and medium was changed every other day up to confluence ( $90 \%$ epithelialized dishes). Sodium fluoride (NaF; Sigma) was added as a stock solution of $1 \mathrm{M}$ in demineralized sterile water. Cells were treated at different concentrations from 0.5 to $5 \mathrm{mM}$ of $\mathrm{NaF}$ for periods of 1,2 , and 3 days under serum-free condition, unless otherwise stated. These concentrations are just lower than the $50 \%$ toxicity of $\mathrm{NaF}$ for $\mathrm{HaCaT}$ (TC50 $=6 \mathrm{mM}$ ) as reported by (Dogan et al. 2002).

To test the reversibility of fluoride effects, fluoride treatment for 24 and $72 \mathrm{~h}$ was terminated by changing the culture medium (DMEM supplemented with $10 \%$ FBS, no fluoride) and allowing further growth for $24 \mathrm{~h}$.

\section{RT-PCR}

$\mathrm{HaCaT}$ cells were treated with low or high dose of $\mathrm{NaF}$ during 24, 48, and $72 \mathrm{~h}$. Cells were then harvested, and total RNA was extracted from cell culture with TriReagent (Molecular Research Center Inc., Cincinnati, $\mathrm{OH}$, USA) according to the manufacturer's instructions. RNA concentration was adjusted to $1 \mu \mathrm{g} / \mu \mathrm{l}$. Total RNA was reverse-transcribed using superscript ${ }^{\mathrm{TM}}$ II Reverse Transcriptase (Invitrogen, Groningen, Netherlands) according to the manufacturer's instructions, and complementary deoxyribonucleic acid (cDNA) was amplified for each keratin, for c/EBP alpha, and for HSC70 by using specific couple of primers (Table 1). The polymerase chain reactions (PCR) contained $2 \mu \mathrm{l}$ of cDNA in $25 \mu \mathrm{l}$ reaction solution, $2.5 \mu \mathrm{l}$ PCR $5 \times$ buffer, $250 \mu \mathrm{M}$ dNTP, $2 \mathrm{mM} \mathrm{MgCl} 2$, $0,5 \mu \mathrm{M}$ forward and reverse primers, and $0.05 \mathrm{U} / \mu \mathrm{l}$ Taq polymerase (Eurobio, Les Ulis, France). The thermocycler was programmed for 25 cycles of $30 \mathrm{~s}$ at the specific annealing temperature (Ta in Table 1). RNA without previous reverse transcription (RT) 
Table 1 Primers used for reverse transcriptionpolymerase chain reaction

\begin{tabular}{|c|c|c|c|c|}
\hline Name and Gene bank & Fragment & Sequenc & & $\mathrm{Ta}\left({ }^{\circ} \mathrm{C}\right)$ \\
\hline KRT1 NM 006121 & 266 & $\begin{array}{l}\text { P1 Fw } \\
\text { P2 Rv }\end{array}$ & $\begin{array}{l}\text { TGGATTTGGAAGTCGGAGTC } \\
\text { GAGGGAGCAGACGGACCATAA }\end{array}$ & 60 \\
\hline KRT10 DQ 896675 & 427 & $\begin{array}{l}\text { P1 Fw } \\
\text { P3 Rv }\end{array}$ & $\begin{array}{l}\text { GGCTGCGGTAGGTTTGAATTT } \\
\text { GGGTGTTGATCTGACTCAAC }\end{array}$ & 60 \\
\hline KRT13 DQ 890652 & 440 & $\begin{array}{l}\text { P1 Fw } \\
\text { P2 Rv }\end{array}$ & $\begin{array}{l}\text { CCAGCAGCATCTTGTACTCTTGGT } \\
\text { TGAAGGAATTTAGCAACCAGGTGG }\end{array}$ & 65 \\
\hline KRT15 DQ 896238 & 390 & $\begin{array}{l}\text { P3 Fw } \\
\text { P4 Rv }\end{array}$ & $\begin{array}{l}\text { TGGTTCTGAGCCTCCATCTCGCAT } \\
\text { AGGTCAATGTGGAGATGGACGCAG }\end{array}$ & 69 \\
\hline KRT19 DQ 895373 & 462 & $\begin{array}{l}\text { P1 Fw } \\
\text { P2 Rv }\end{array}$ & $\begin{array}{l}\text { GAGGTGGATTCCGCTCCGGG } \\
\text { ATCTTCCTGTCCCTCGAGCAG }\end{array}$ & 66 \\
\hline HSC70 Y00481 & 200 & $\begin{array}{l}\text { P1 Fw } \\
\text { P2 Rv }\end{array}$ & $\begin{array}{l}\text { AGCATCGTTTAAGACACCGT } \\
\text { AAGTTTGCAACCCCATCATC }\end{array}$ & 55 \\
\hline c/EBP alpha NM4364.2 & 246 & $\begin{array}{l}\text { P1 Fw } \\
\text { P2 Rv }\end{array}$ & $\begin{array}{l}\text { AACCTTGTGCCTTGGAAATG } \\
\text { CCCTATGTTTCCACCCCTTT }\end{array}$ & 59 \\
\hline Actin DQ 894128 & 350 & $\begin{array}{l}\text { P1 Fw } \\
\text { P2 Rv }\end{array}$ & $\begin{array}{l}\text { AAACTGGAACGGTGAAGGTG } \\
\text { TCAAGTTGGGGGACAAAAAG }\end{array}$ & 60 \\
\hline
\end{tabular}

served as a control for absence of genomic DNA contamination. In addition, amplification of beta-actin sequences from the same samples served as positive controls. All PCR reactions were performed with a Perkin Elmer Gene Amp PCR system 2400 (Boston, MA, USA). The PCR products were separated on $2 \%$ agarose gel, stained with ethidium bromide, and photographed under ultraviolet illumination.

Western blot analysis

$\mathrm{HaCaT}$ cells were treated with 0.5 and $5 \mathrm{mM} \mathrm{NaF}$ during 24, 48, and $72 \mathrm{~h}$. Cells were harvested, and total protein was extracted in $2 \times$ denaturing buffer (Prosieve 50 protocol, Cambrex BioScience, Rockland, ME, USA). The mix was heated for $15 \mathrm{~min}$ at $95^{\circ} \mathrm{C}$, sonicated, and centrifuged. Bradford technique was used for proteins dosage; equal amounts were electrophoresed on $12 \%$ acrylamide sodium dodecyl sulfate (SDS) gels. The separated bands were transferred onto PVDF hybond membranes (Amersham Biosciences, Freiburg, Germany). The first antibody (Table 2) was incubated for $1 \mathrm{~h}$ at $24^{\circ} \mathrm{C}$. Actin antibody was added to each membrane and served as positive internal control. After washing, the membranes were incubated with goat anti-mouse horseradish phosphate labeled immunoglobulins (DAKO, Glostrup, Denmark) for $1 \mathrm{~h}$ at $24^{\circ} \mathrm{C}$. After washing, Super Signal West-Pico Luminol/Enhancer solution served as chemiluminescent reagent (Pierce, Rock- ford, IL, USA). The reaction was visualized on Kodak Biomax XAR film.

Immunocytochemistry

HaCaT cells grown on glass cover slides were treated with low or high dose $\mathrm{NaF}$ during 24,48 , and $72 \mathrm{~h}$. Treatment was started when cells had attained $90 \%$ confluency. For the reversibility test, cells were kept with normal growth medium and $10 \%$ FBS after the fluoride treatment. Immunocytochemistry was performed after washing of slides in PBS and fixation in $-20^{\circ} \mathrm{C}$ precooled methanol/ethanol $(1: 1 v)$ for 5 min. Slips were incubated with primary mouse monoclonal antibodies for $1 \mathrm{~h}$ at $37^{\circ} \mathrm{C}$ (Table 2). The reaction sites were detected by alexa 594 fluor labeled donkey anti-mouse immunoglobulin G (Molecular Probes, USA). Samples were mounted in Fluoprep aqueous solution (BioMérieux, Marcy l'Etoile,

Table 2 Antibodies

\begin{tabular}{llll}
\hline Antigen & Antibody clone & MW (kDa) & Distributor \\
\hline K1/10 & LH1 & $68(\mathrm{~K} 1) ; 56.5(\mathrm{~K} 10)$ & Acris \\
K13 & 1C7 & 54 & Sigma \\
K15 & LHK15 & 52 & Novocastra \\
K19 & B170 & 40 & Novocastra \\
Beta-actin & AC-74 & 42 & Sigma \\
HSP70 & A5A & 70 & Abcam \\
\hline
\end{tabular}


France) and examined with a Leitz DMRB microscope equipped with epifluorescence illumination.

\section{Ultrastructural analysis}

The cells were kept in culture with and without $\mathrm{NaF}$ at low or high dose for 3 weeks on nitrocellulose membranes, in order to allow stratification. All cultures were supplemented with $1 \%$ fetal calf serum (FCS). Ultrastructural examination was performed as described previously (Shabana et al. 1994). The cells were washed in sodium cacodylate buffer containing $0.1 \mathrm{M}$ sucrose, $\mathrm{pH} 7.4$, fixed for $30 \mathrm{~min}$ in $2 \%$ glutaraldehyde in washing buffer, and post-fixed for $30 \mathrm{~min}$ in $0.5 \%$ osmium tetroxide in cacodylate buffer. After washing and dehydration in increasing concentrations of ethanol solutions and propylene oxide, the samples were embedded in epon-araldite. The blocks were sectioned vertically to examine epithelial stratification. Thin sections were stained with lead citrate for $30 \mathrm{~min}$ and examined with a Philips CM 12 electron microscope.

\section{Results}

RNA analysis by RT-PCR

$\mathrm{HaCaT}$ cells were treated with $\mathrm{NaF}$ at low and high dose for 24,48 , and $72 \mathrm{~h}$. RNA was extracted, reverse-transcribed, and specific keratin-coding, c/ EBP alpha-coding, and HSP70-coding segments were amplified under standard conditions. Non-treated cultures (C) were processed in parallel. After amplification, samples were electrophoresed on agarose gels, and the presence of amplified fragments was revealed by ethidium bromide staining of bands of the defined sizes.

In the course of the fluoride treatment, the band strengths of K13 and K19 remained the same, as did the actin band (Fig. 1). Bands for K1, K10, and K15 were reduced in the samples subjected to high dose fluoride treatment; no significant change occurred when cells were treated with the low dose at any time period. Treatments for 24,48 , and $72 \mathrm{~h}$ reduced K1, K10, and K15 RNA similarly (Fig. 1). We also tested the presence of RNA coding for factors regulating $\mathrm{K} 1$ and K10 expression. RNA for c/EBP alpha, an upstream enhancer factor, was markedly reduced by the high dose NaF. c/EBP alpha reduction (Fig. 1) was consistent in the three time intervals, and thus closely correlated with K1 and K10 protein and RNA expression.

We also tested the reversibility of the fluoride effect on keratins 10, 15, and 19. After $24 \mathrm{~h}$ of withdrawal, bands for K19 were unchanged, whereas $\mathrm{K} 10$ and K15 remained at the low level obtained with fluoride treatment (Fig. 5b). HSC70 expression was enhanced after 24 and $72 \mathrm{~h}$ of treatment with $5 \mathrm{mM}$ $\mathrm{NaF}$ (Fig. 5c). After withdrawal, the HSC70 band

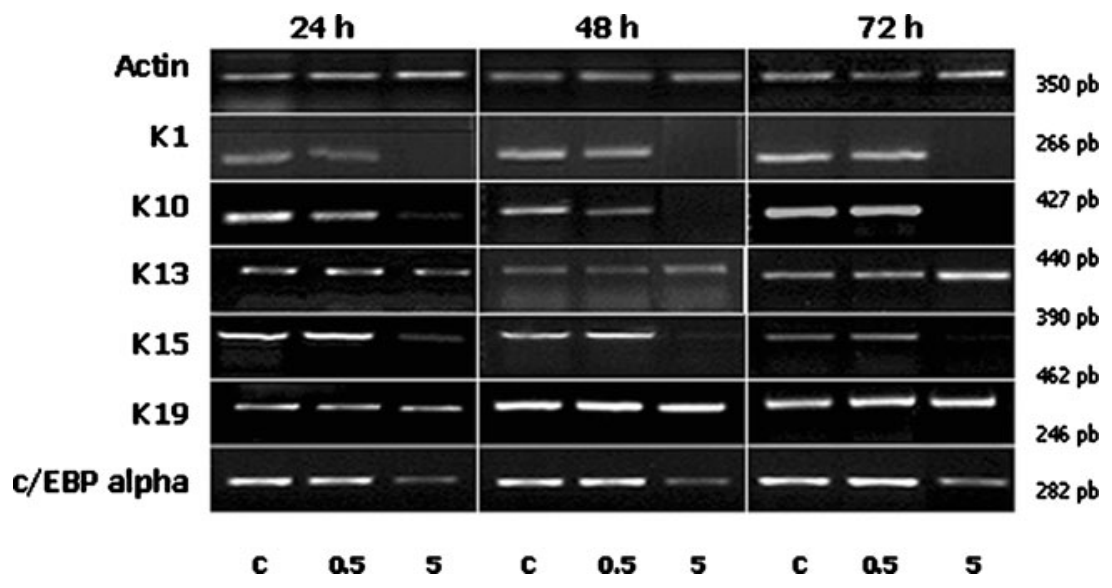

Fig. 1 RNA analysis by reverse transcription-polymerase chain reaction (RT-PCR). Total RNA was harvested after 24, 48, and $72 \mathrm{~h}$ of low $(0.5 \mathrm{mM})$ or high dose $(5 \mathrm{mM}) \mathrm{NaF}$ treatment as indicated, followed by semiquantitative RT-PCR analysis of RNA. $C$, cells without fluoride treatment. Actin RNA served as internal control. Keratins 1, 10, 13, 15, and 19 represent the

amplified fragments of the different mRNA keratins. K1/10 and K15 detection diminished after high dose of NaF treatment. K13 and K19 remained unchanged at high dose. Transcription factor c/EBP alpha diminished in cells treated at high dose of $\mathrm{NaF}$ at the three times of treatment 
decreased to the level of control cells. Thus, the fluoride effect was reversible for HSC70 expression, but not for that of keratins 10 and 15 .

Analysis of expression of keratins by Western blots

Cells from cultures as in Fig. 1 were harvested, and total protein was extracted. Equal protein amounts were loaded on SDS polyacrylamide gels and electrophoresed. Proteins were transferred to membranes, and specific keratins were revealed by an antibody reaction followed by luminescence detection (Fig. 2). Presence of actin was tested as an internal loading control; its band strength was unaffected by fluoride. Also, the band strengths for K13 and K19 were similar in all samples, suggesting that fluoride did not influence their synthesis. Bands for $\mathrm{K} 1, \mathrm{~K} 10$, and $\mathrm{K} 15$ became fainter or invisible in cells treated with the high fluoride dose. The low dose did not change expression of these proteins. Treatment for 24, 48, and $72 \mathrm{~h}$ gave similar results (Fig. 2).

Immunolabeling of cell cultures

Semiconfluent cultures were treated with fluoride for 1,2 , and 3 days and labeled by antisera as indicated.
Similar results were obtained at the three time intervals; only the 24-h results are shown (Fig. 3). Anti-keratin antibodies stained the cytoplasm of $\mathrm{HaCaT}$ cells. In parallel, DAPI was added in order to stain cell nuclei. Any view field in the microscope was photographed twice: one time for the blue DAPI fluorescence and one time for the red fluorescence, indicating presence of the specific keratin. For K19, antibody and DAPI labeling detected the same pattern in the cell lawn at both fluoride concentrations and the control. Anti-K13 serum detected frequent cell clusters, indicating expression of K13 in neighborhoods of a few cells. Cells outside of these neighborhoods did not display K13. Addition of fluoride at low or high dose did not change this pattern. With anti-K1/K10, clustering of positive cells was detected too. Here, the high fluoride dose suppressed expression, whereas the low dose had no effect (b in Fig. 3). $\mathrm{K} 15$ was expressed in the control cultures in $30 \%$ of the population in an even distribution ( $\mathrm{m}$ in Fig. 3). The low dose of fluoride provoked an uneven suppression of K15 resulting in a patchy labeling ( $\mathrm{n}$ in Fig. 3); the high fluoride dose suppressed all K15 (o in Fig. 3).

Reversibility was assessed during withdrawal for $24 \mathrm{~h}$, following $\mathrm{NaF}$ treatment for 24 (Fig. 5a) and

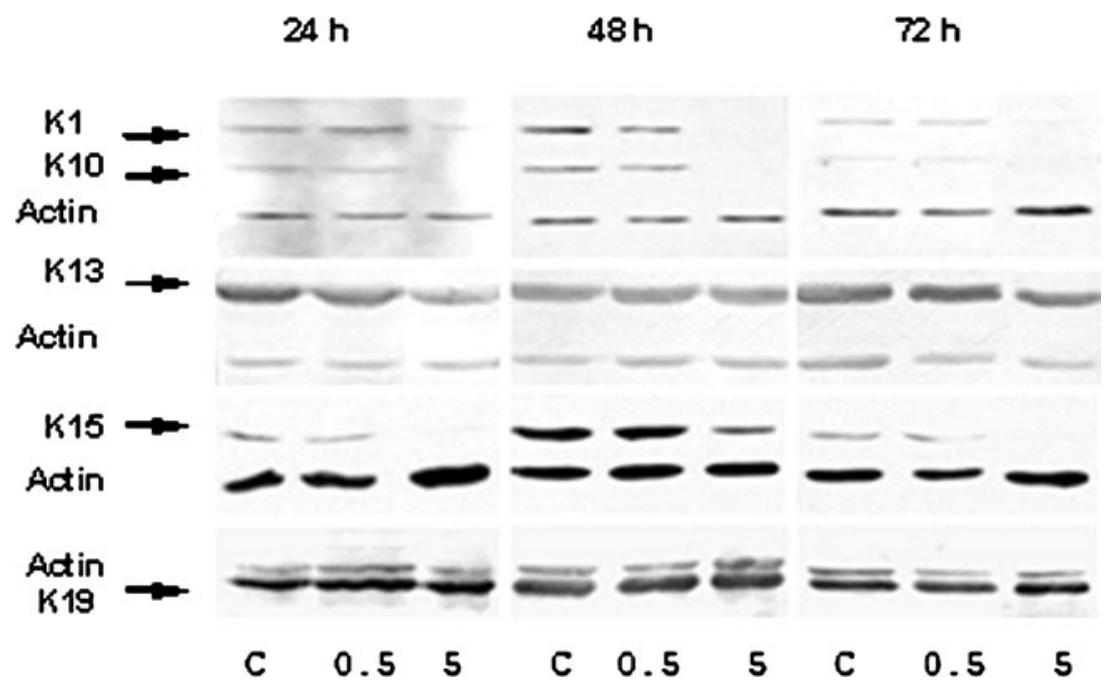

Fig. 2 Analysis of expression of keratins by Western blot. Total protein was isolated from $\mathrm{HaCaT}$ cells after treatment with low $(0.5 \mathrm{mM})$ or high dose $(5 \mathrm{mM})$ of $\mathrm{NaF}$ during 24,48 , and $72 \mathrm{~h}$ and subjected to Western blotting. $C$, non-treated cells. Monoclonal antibodies LH1, 1C7, LHK 15, and b 170, respectively, against keratins $1 / 10,13,15$, and 19 reacted with the expected bands at $56,52,62,57$, and $40 \mathrm{kDa}$, respectively.

Anti-actin serum was added as control, eliciting a band at $40 \mathrm{kDa}$. Keratins $1 / 10(\mathrm{~K} 1 / 10)$ and 15 (K15) proteins were not detected after high dose of $\mathrm{NaF}$ treatment during the three times of observation. Keratin 13 (K13) and keratin 19 (K19) detection was not modified at any exposure time neither at low dose and high dose of $\mathrm{NaF}$ treatment 
Fig. 3 Immunocytochemistry of keratins. $\mathrm{HaCaT}$ cells were treated for 24,48 , and $72 \mathrm{~h}$ with sodium fluoride at low $(0.5 \mathrm{mM})$ or high dose $(5 \mathrm{mM})$ of NaF. Only the 24-h treatment pattern of expression is shown; similar profiles were obtained after 48 and $72 \mathrm{~h}$. Monoclonal antibodies as in Fig. 2 were applied. $C$, non-treated cells. Nuclear staining with DAPI was included to show cell density from all cover slips. The expression of $\mathrm{K} 1 / 10$ and $\mathrm{K} 15$ was decreased after low dose and high dose treatment, whereas K13 and K19 expression remained unchanged. Note the pattern of expression of $\mathrm{K} 1 / 10$ and $\mathrm{K} 15$ : positive cells occur in clusters. Expression of K15 and K1/ 10 decreased substantially at high dose $\mathrm{NaF}$
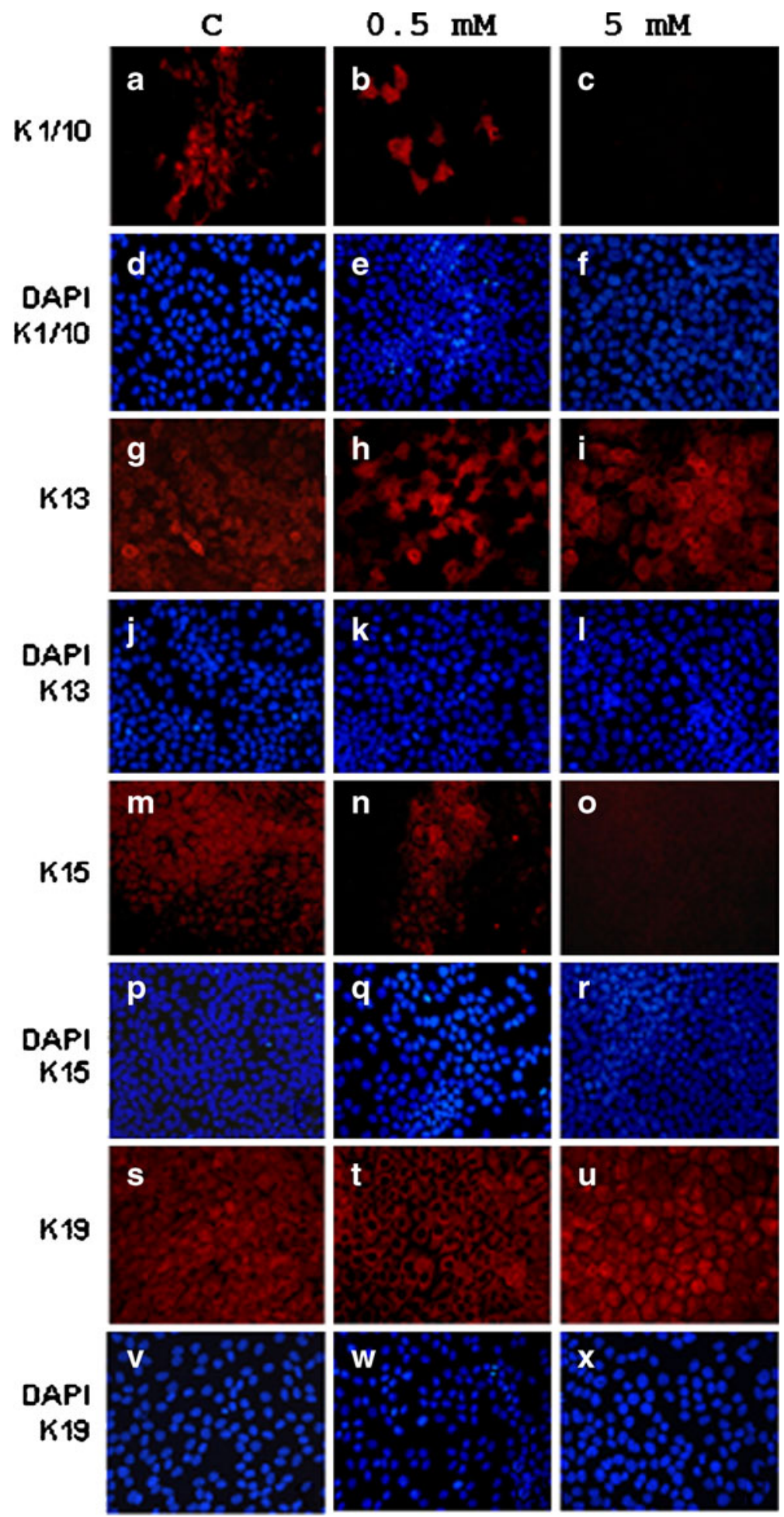
$72 \mathrm{~h}$ (not shown). The presence of K10 and K15 was assayed by immunocytochemistry, and cell nuclei were displayed by DAPI coloration. It was found that the expression of $\mathrm{K} 10$ and $\mathrm{K} 15$ was not restored; therefore, the fluoride effect was irreversible under our conditions. Fluoride treatment for 24 and $72 \mathrm{~h}$ gave the same results.

The expression of HSP70, a cytoplasmic marker of oxidative stress, was increased after high dose of NaF-treated cells. Most HSP70 appeared in granules that increased in number upon fluoride treatment (Fig. 4). The size of the granules was similar to those seen at the EM level in cells treated with the high fluoride dose (see below). This result suggested that $\mathrm{NaF}$ at high dose induced cellular stress. It should be noted that indications of apoptosis or necrosis, such as chromatin condensation and fragmentation, vacuoles, and cell fragmentation, were not observed (Figs. 3, 4 and 5).

\section{Ultrastructural examination}

The cells were kept in culture at low or high dose and without $\mathrm{NaF}$ for 3 weeks in order to provide information about the stratification capacity and to examine eventual pathological effects of fluoride treatment. For this study, all cultures were supplemented with $1 \%$ FCS. In control cultures (Fig. 6), the cells formed a stratified epithelium made of cubical basal cells and overlaid with two to three polygonal suprabasal cells (Fig. 6a). Desmosomal structures were rather small and few at sites of cell-cell contacts. The keratin intermediate filaments were sparsely scattered in the cytoplasm and associated with the desmosomes at the cell membrane. $\mathrm{NaF}$ treatment at either dose did not alter vital structures such as the nucleus, mitochondria, Golgi apparatus, desmosomes, cytoskeletal morphology, or the cell membrane (Fig. 6e, f) when compared to control (Fig. 6d). In the cytoplasm, electron dense bodies were observed resembling myelin figures or stress granules with distinct outlines. The number of these granules increased markedly in the presence of fluoride (Fig. 4). Stratification was unaffected at the low fluoride dose; however, at high dose, the epithelium remained unstratified (Fig. 6c) with flattened cells attached together by small desmosomes. Apoptotic features such as chromatin condensation, nuclear fragmentation, or membrane blebbing did not occur at high fluoride dose, neither were necrotic characteristics observed, such as large vacuoles or cell fragments. It was concluded that the high $\mathrm{NaF}$ dose exerted some cell stress, but no apoptosis or toxic effects leading to necrosis.

\section{Discussion}

In this study, treatment of $\mathrm{HaCaT}$ keratinocytes with high dose of $\mathrm{NaF}$ resulted in an inhibition of cell differentiation. The pattern of keratin expression was changed, maintaining a pattern typical for nonstratified cells, and cells failed to undergo stratification. The proliferation and viability of the cells
Fig. 4 Analysis of HSP expression. Cells were cultured on cover slips and treated with $\mathrm{NaF}$ for $24 \mathrm{~h}$. Immunocytochemistry was performed with HSP70 antibody (clone 5A5 from Abcam), revealed by red fluorescence. Signal appears in cytoplasmic granules at high dose of fluoride treatment

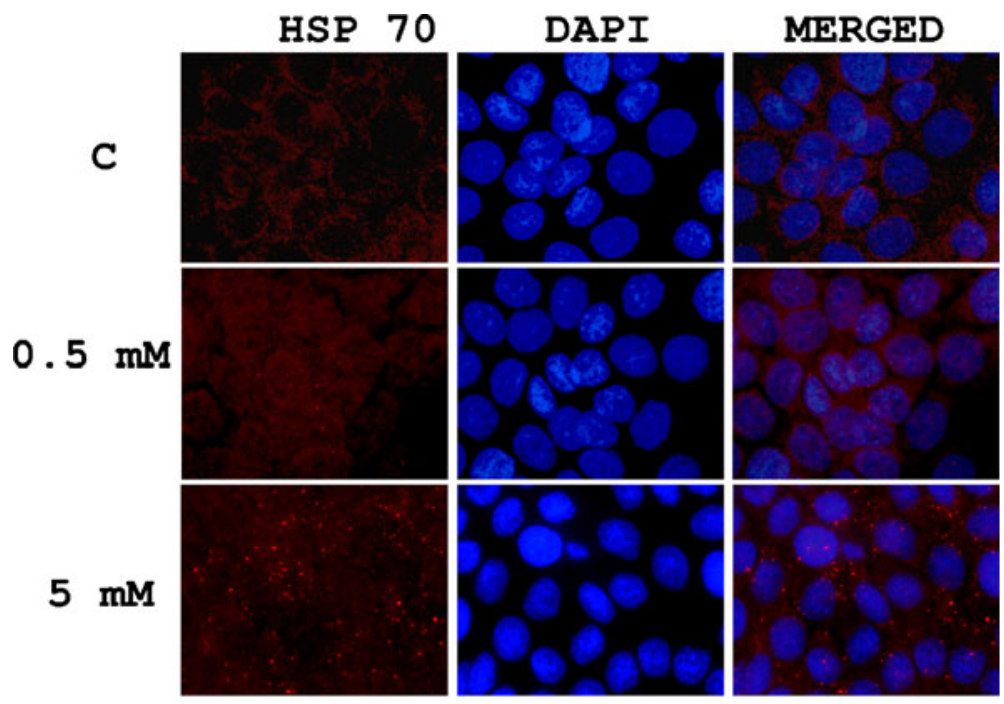


Fig. 5 Reversibility of

fluoride effects. After treatment with fluoride for 24 and $72 \mathrm{~h}$, fluoride was withdrawn by changing the culture medium (Dulbecco's modified Eagle's medium supplemented with $10 \%$ fetal bovine serum), followed by further growth for $24 \mathrm{~h}$. a Cells were fixed and subjected to immunocytochemistry for the presence of K10 and K15. Cell nuclei were displayed by DAPI coloration. b RNA was isolated, reversed transcribed, and amplified. Displayed cells had been treated by fluoride for $24 \mathrm{~h}$; cells treated for $72 \mathrm{~h}$ gave similar results. K10 and K15 expression appeared reduced even after the withdrawal. c RNA was isolated after 24 and $72 \mathrm{~h}$ of fluoride treatment, reversed transcribed, and the HSC70 sequences in the cDNA were amplified. Expression of HSC70 was induced during treatment, albeit after withdrawal of fluoride treatment HSC70 did not changed. K19 expression remained unchanged a

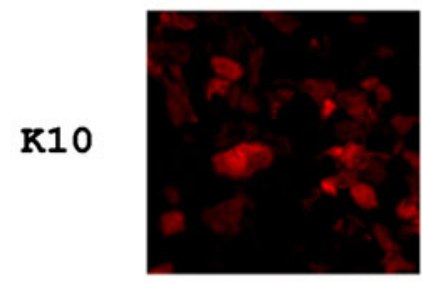

C

$0.5 \mathrm{mM}$
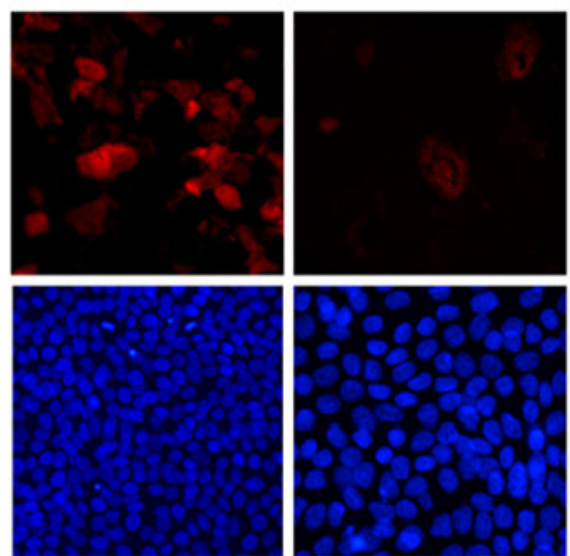

DAPI

K10

K15
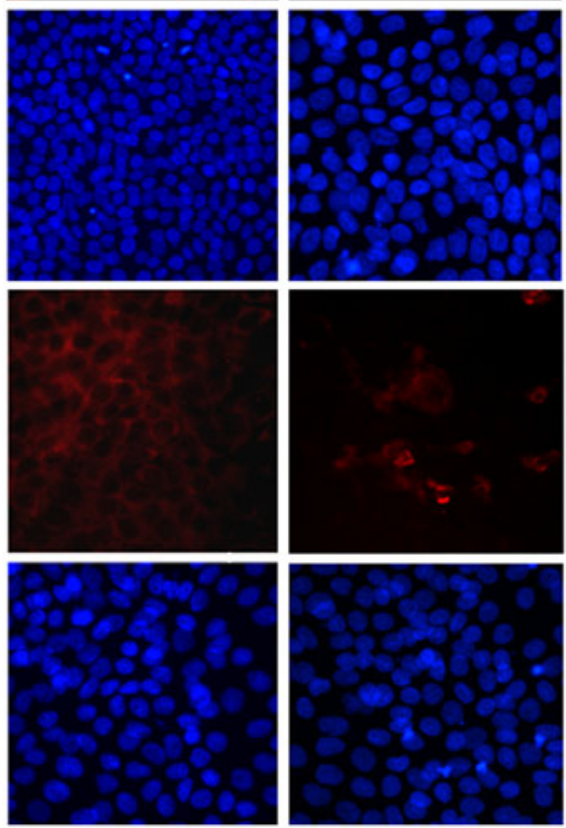

b

DAPI

K15

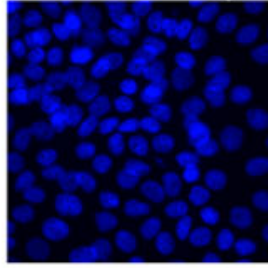

$24 \mathrm{~h}$

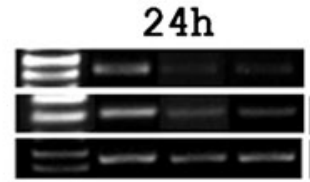

M
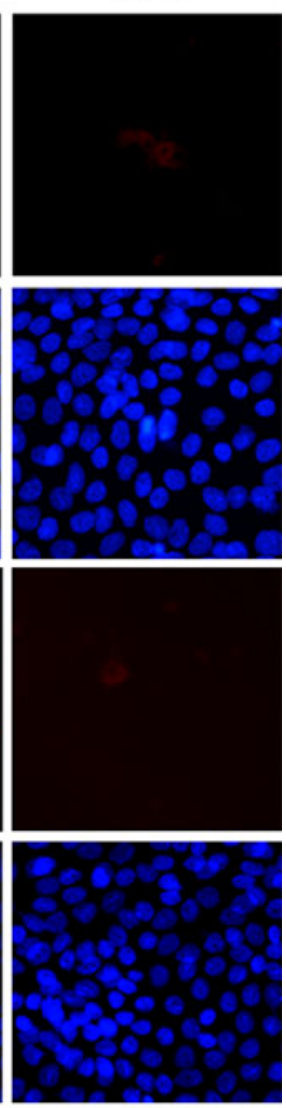

$72 \mathrm{~h}$

\section{C \\ Treatment \\ Withdrawal

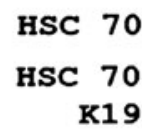

remained intact, apoptosis features were absent, and the cellular ultrastructure was preserved after 3 weeks of $\mathrm{NaF}$ treatment albeit with the appearance of stressrelated granules. Cell stress was corroborated by the induction of HSP70 and its deposition in cytoplasmic inclusions. In particular, we show for the first time that the high dose of $\mathrm{NaF}$ selectively suppressed terminal differentiation keratins $\mathrm{K} 1 / 10$ and stratification-related keratin $\mathrm{K} 15$, at both mRNA and protein levels. Surprisingly, the effect of $\mathrm{NaF}$ at high dose on HaCaT cells seemed to be not reversible. It seems probable that the fluoride effects on keratin gene expression are mediated by the CCAAT/enhancer binding protein (c/EBP) family member (Oh and Smart 1998), because this factor appeared reduced by fluoride too. Concerning stratification, we suggest 

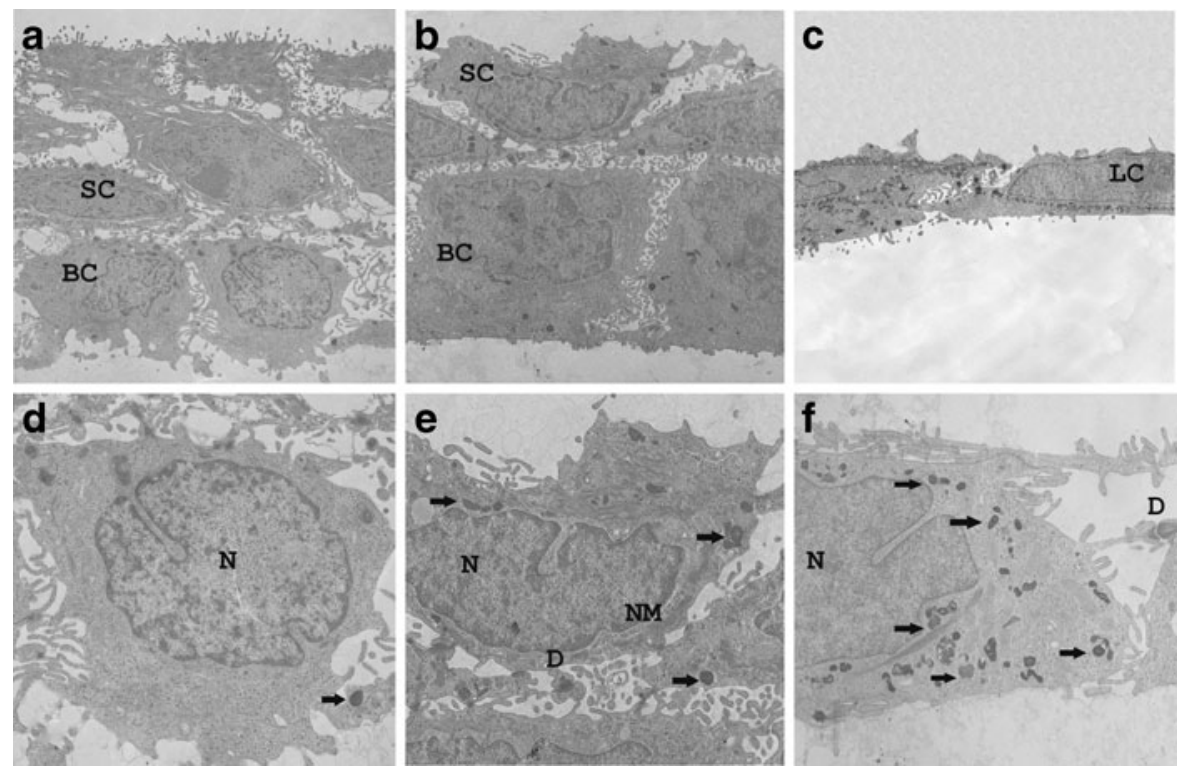

Fig. 6 Stratification of $\mathrm{HaCaT}$ cells. HaCaT cells were treated at low $(0.5 \mathrm{mM})$ and high $(5 \mathrm{mM})$ of $\mathrm{NaF}$ for 3 weeks on a nitrocellulose membrane to achieve stratification. $C$, nontreated cells. In overviews, control (a) and low dose (b) membrane showed partial stratification with cubic basal cells and polygonal suprabasal cells. At high dose (c), HaCaT cells

that cell contacts are compromised by misexpression of other sensible components. The altered keratins were expressed in cell clusters, whereas the surrounding cells remained unlabeled. Expression of uniformly distributed keratins K13 and K19 remained unchanged. We hypothesize that this cell grouping represents early stages in the stratification process. Fluoride would interrupt the process, before K1/10 and K15 start to accumulate. Concerning K13, its expression in parceled small groups of cells was not influenced by fluoride, which would locate the fluoridesensitive state after the initial clustering itself.

Fluoride concentrations in our experiments have been chosen according to previous work that resulted in measurable effects on culture cells (Dogan et al. 2002). They are well below those used for topic application in the clinic (Walsh et al. 2010); however, the time of treatment was longer than applied by the dentist.

We used serum-free conditions for fluoride treatment with the rationale to minimize cell proliferation activity during the assay period. In this way, any effects of superconfluence on cell vitality, with possible interference with gene expression and protein or RNA intactness, were avoided. During the experiments described in Figs. 1, 2, and 3, cells remained appear as monolayer. Detailed views $(\mathbf{d}-\mathbf{f})$ showed normal cells with intact nucleus $(N)$, nuclear membrane $(N M)$, and desmosomes $(D)$. The cytoplasm of treated cells is normal with normal organelles (Golgi, ER, etc.; not shown), although there are granules (f, black arrows)

uniformly in a subconfluent state. Clear distinction of individual cells was essential for Fig. 3 in order to reveal the heterogeneity of the cultures in a sense that particular assemblies expressed stratification-specific keratins. The stratification assay (Fig. 6) required however superconfluent cultures that proliferated during the assay period. In this experiment, it is possible that cell density was influenced by the presence of fluoride at high dose (Dogan et al. 2002). According to ultrastructural criteria, apoptosis or necrosis of cells did not occur (compare Wurtz et al. (2008)). Concerning cell differentiation, we found a clear difference between basal cell morphology and that of the stratification layer in the control and low dose samples, whereas in the high dose sample, cell morphology was uniform and resembled that of undifferentiated, growing cells (Fig. 6). HaCaT cells were earlier employed in tissue engineering systems (Boelsma et al. 1999) for the development of artificial skin equivalents, because of their stratification capacity in monoculture (Raynov et al. 2008). We confirmed their capability to stratify; however, fluoride at high dose abolished this property. Apparently, the correct culture conditions are essential for the maintenance of the cellular phenotype. Low doses did 
not alter the cells' properties, which illustrate the resistance of keratinocytes as compared to other cell types tested in this respect.

Ultrastructural examination revealed stress-related granules in fluoride-treated cells. In addition, PCR confirmed the induction of HSC70, a stress-related protein, and immunolabeling revealed its presence in cytoplasmic foci (Fig. 4).

Presence of stress indicators, but absence of apoptosis and necrosis features, as well as ongoing cell proliferation in stress conditions, might suggest that withdrawal of fluoride restores the normal phenotype of $\mathrm{HaCaT}$ cells immediately. However, we found that the fluoride-related keratin expression pattern was maintained after the removal of fluoride and further cell growth. This would suggest that fluoride-induced changes not only bring about stress but they also exert in addition an independent effect on cells. In this sense, the changes of the keratin pattern may not represent a stress effect.

Concerning effects of keratin misexpression in vivo, deficient expression of single keratins is generally compensated by other keratins. However, for the case of the double KO k18-19, severe embryonal disturbances have been observed (Arin 2009), and mutations in keratins k1-10 as well as k13 resulted in distinct phenotypes of adult human beings (Arin 2009), in particular when exposed to environmental stress. If keratin gene expression would be disturbed by fluoride in vivo in a similar way as described here, it is conceivable that cell interactions could be altered. In this way, epithelia formation might be compromised so that organs like intestine, kidney, and lung exhibit functional disturbances. In addition, changes in cell metabolism would be expected that could further contribute to reduced organ function.

The observed effects on keratinocytes occurred at concentrations that were considerably higher than concentrations affecting osteoblasts, odontoblasts, and especially ameloblasts. These differences have repeatedly been observed. Considering tissue growth and organ development as a whole, the most striking effects of fluoride occur on the formation of mineralized tissue. Effects on epithelia during development would thus only take place if the general development and tissue formation were totally deranged with catastrophic consequences for the organism as a whole. Therefore, consequences of fluoride as described here are likely to concern renewing epithelia of the adult organism. Examples of possible local fluoride exposures are lung epithelia through the air, kidney epithelia due to secreted fluoride, or mucosal epithelia due to ingested fluoride (Whitford 1990; Gharzouli et al. 2000).

The mechanism of fluoride action is unknown; the wide variations of effective fluoride concentrations suggest that different cell types react in a different way. It has been proposed that cells may occupy a set of physiological states, biological attractors (Kitano 2004). These states are discrete, because the total set of cell products must accommodate metabolic functions, gene regulation, cell communication etc., and it is likely that only few physiological states can match all requirements. Robustness towards environmental changes is favored if cells may switch between several states. Presence of fluoride might force cells to occupy states different from control cells, whereby the synthesis of many cell products may be altered. It is conceivable that the effective concentration depends on the cell type; therefore, this hypothesis is consistent with grossly different fluoride levels affecting different cell types. It seems likely that cells of epithelia have been selected during evolution to support variable ranges of external factors, whereas less pressure is exerted on mesenchymal cells, not forming extracorporal surfaces.

Acknowledgements We thank Dr. N.E. Fusenig for kindly providing HaCaT cell line to our laboratory. We thank Mrs. Martine Oboeuf for EM technique. This work was supported by a Convention Industrielle de Formation par la Recherche (CIFRE) grant in collaboration with Sanofi-Aventis OTC directed by P. Ben-Soussen (deceased), medical director, Sanofi-Aventis OTC and especially C. Gal-Jallat, scientific interlocutor for Sanofi-Aventis OTC. In memoriam to Dr. Isabelle Fernandes, who was a great friend, a great colleague, and a great researcher.

Open Access This article is distributed under the terms of the Creative Commons Attribution Noncommercial License which permits any noncommercial use, distribution, and reproduction in any medium, provided the original author(s) and source are credited.

\section{References}

Arin MJ. The molecular basis of human keratin disorders. Hum Genet. 2009;125(4):355-73.

Bevilacqua E, Wang X, Majumder M, Gaccioli F, Yuan CL, et al. eIF2alpha phosphorylation tips the balance to apoptosis 
during osmotic stress. J Biol Chem. 2010;285(22):17098111.

Boelsma E, Verhoeven MC, Ponec M. Reconstruction of a human skin equivalent using a spontaneously transformed keratinocyte cell line (HaCaT). J Invest Dermatol. 1999;112(4):489-98.

Boukamp P, Petrussevska RT, Breitkreutz D, Hornung J, Markham A, et al. Normal keratinization in a spontaneously immortalized aneuploid human keratinocyte cell line. J Cell Biol. 1988;106(3):761-71.

Dogan S, Gunay H, Leyhausen G, Geurtsen W. Chemicalbiological interactions of $\mathrm{NaF}$ with three different cell lines and the caries pathogen Streptococcus sobrinus. Clin Oral Investig. 2002;6(2):92-7.

Dominguez JH, Garcia JG, Rothrock JK, English D, Mann C. Fluoride mobilizes intracellular calcium and promotes $\mathrm{Ca} 2+$ influx in rat proximal tubules. Am $\mathrm{J}$ Physiol. 1991;261(2 Pt 2):F318-27.

Farley JR, Tarbaux N, Hall S, Baylink DJ. Evidence that fluoridestimulated $3[\mathrm{H}]$-thymidine incorporation in embryonic chick calvarial cell cultures is dependent on the presence of a bone cell mitogen, sensitive to changes in the phosphate concentration, and modulated by systemic skeletal effectors. Metabolism. 1988;37(10):988-95.

Gharzouli K, Amira S, Khennouf S, Gharzouli A. Effects of sodium fluoride on water and acid secretion, soluble mucus and adherent mucus of the rat stomach. Can J Gastroenterol. 2000;14(6):493-8.

Hatakeyama S, Hayashi S, Yoshida Y, Otsubo A, Yoshimoto K, et al. Retinoic acid disintegrated desmosomes and hemidesmosomes in stratified oral keratinocytes. J Oral Pathol Med. 2004;33(10):622-8.

Hellwig E, Lennon AM. Systemic versus topical fluoride. Caries Res. 2004;38(3):258-62.

Hodge HC, Smith FA. Occupational fluoride exposure. J Occup Med. 1977;19(1):12-39.

Kedersha N, Anderson P. Mammalian stress granules and processing bodies. Methods Enzymol. 2007;431:61-81.

Kirfel J, Magin TM, Reichelt J. Keratins: a structural scaffold with emerging functions. Cell Mol Life Sci. 2003;60(1):5671.

Kitano H. Biological robustness. Nat Rev Genet. 2004;5(11):82637.

Lau KH, Yoo A, Wang SP. Aluminum stimulates the proliferation and differentiation of osteoblasts in vitro by a mechanism that is different from fluoride. Mol Cell Biochem. 1991;105(2):93-105.

Leube RE, Bader BL, Bosch FX, Zimbelmann R, Achtstaetter $\mathrm{T}$, et al. Molecular characterization and expression of the stratification-related cytokeratins 4 and 15. J Cell Biol. 1988;106(4):1249-61.

Li Y, Decker S, Yuan ZA, Denbesten PK, Aragon MA, et al. Effects of sodium fluoride on the actin cytoskeleton of murine ameloblasts. Arch Oral Biol. 2005;50(8):681-8.

Lloyd C, Yu QC, Cheng J, Turksen K, Degenstein L, et al. The basal keratin network of stratified squamous epithelia: defining K15 function in the absence of K14. J Cell Biol. 1995;129(5):1329-44.
Maytin EV, Lin JC, Krishnamurthy R, Batchvarova N, Ron D, et al. Keratin 10 gene expression during differentiation of mouse epidermis requires transcription factors $\mathrm{C} / \mathrm{EBP}$ and AP-2. Dev Biol. 1999;216(1):164-81.

Moll R, Franke WW, Schiller DL, Geiger B, Krepler R. The catalog of human cytokeratins: patterns of expression in normal epithelia, tumors and cultured cells. Cell. 1982;31 (1):11-24.

Oh HS, Smart RC. Expression of CCAAT/enhancer binding proteins $(\mathrm{C} / \mathrm{EBP})$ is associated with squamous differentiation in epidermis and isolated primary keratinocytes and is altered in skin neoplasms. J Invest Dermatol. 1998;110 (6):939-45.

Partanen S. Inhibition of human renal acid phosphatases by nephrotoxic micromolar concentrations of fluoride. Exp Toxicol Pathol. 2002;54(3):231-7.

Pi J, Diwan BA, Sun Y, Liu J, Qu W, et al. Arsenic-induced malignant transformation of human keratinocytes: involvement of Nrf2. Free Radic Biol Med. 2008;45(5):651-8.

Raynov AM, Choung YH, Park HY, Choi SJ, Park K. Establishment and characterization of an in vitro model for cholesteatoma. Clin Exp Otorhinolaryngol. 2008;1(2):86-91.

Shabana AH, Oboeuf M, Forest N. Quantitative ultrastructural study of acrylamide induced cytoplasmic desmosome-like structures in cultured rat keratinocytes. Epithelial Cell Biol. 1994;3(3):102-11.

Shim M, Powers KL, Ewing SJ, Zhu S, Smart RC. Diminished expression of $\mathrm{C} / \mathrm{EBPalpha}$ in skin carcinomas is linked to oncogenic Ras and reexpression of C/EBPalpha in carcinoma cells inhibits proliferation. Cancer Res. 2005;65(3):861-7.

ten Cate JM. Current concepts on the theories of the mechanism of action of fluoride. Acta Odontol Scand. 1999;57(6):325-9.

Thrane EV, Refsnes M, Thoresen GH, Lag M, Schwarze PE. Fluoride-induced apoptosis in epithelial lung cells involves activation of MAP kinases p38 and possibly JNK. Toxicol Sci. 2001;61(1):83-91.

Turner CH, Owan I, Brizendine EJ, Zhang W, Wilson ME, et al. High fluoride intakes cause osteomalacia and diminished bone strength in rats with renal deficiency. Bone. 1996;19(6):595-601.

Walsh T, Worthington HV, Glenny AM, Appelbe P, Marinho VC, Shi X. Fluoride toothpaste of different concentrations for preventing dental caries in children and adolescents. The Cochrane Data Base Syst Rev. 2010;(1):CD007868.

Waseem A, Dogan B, Tidman N, Alam Y, Purkis P, et al. Keratin 15 expression in stratified epithelia: downregulation in activated keratinocytes. J Invest Dermatol. 1999;112(3):362-9.

Wergedal JE, Lau KH, Baylink DJ. Fluoride and bovine bone extract influence cell proliferation and phosphatase activities in human bone cell cultures. Clin Orthop Relat Res. 1988;233:274-82.

Werner S, Munz B. Suppression of keratin 15 expression by transforming growth factor beta in vitro and by cutaneous injury in vivo. Exp Cell Res. 2000;254(1):80-90.

Whitford GM. The physiological and toxicological characteristics of fluoride. J Dent Res. 1990;69(Spec Issue):539-49 (discussion 556-537). 
Wurtz T, Houari S, Mauro N, MacDougall M, Peters H, et al. Fluoride at non-toxic dose affects odontoblast gene expression in vitro. Toxicology. 2008;249(1):26-34.

Xu H, Hu LS, Chang M, Jing L, Zhang XY, et al. Proteomic analysis of kidney in fluoride-treated rat. Toxicol Lett. 2005;160(1):69-75.
Yan Q, Zhang Y, Li W, Denbesten PK. Micromolar fluoride alters ameloblast lineage cells in vitro. J Dent Res. 2007;86 (4):336-40.

Zager RA, Iwata M. Inorganic fluoride. Divergent effects on human proximal tubular cell viability. Am J Pathol. 1997;150(2):735-45. 